\title{
Enzymatic Saccharification and Ethanol Fermentation of Reed Pretreated with Liquid Hot Water
}

\author{
Jie Lu, ${ }^{1,2}$ XueZhi Li, ${ }^{1}$ Jian Zhao, ${ }^{1}$ and Yinbo $Q u^{1}$ \\ ${ }^{1}$ State Key Laboratory of Microbial Technology, Shandong University, Jinan 250100, China \\ ${ }^{2}$ Dalian Polytechnic University, Dalian 116034, China \\ Correspondence should be addressed to Jian Zhao, zhaojian@sdu.edu.cn
}

Received 8 June 2012; Revised 22 August 2012; Accepted 5 September 2012

Academic Editor: Anuj K. Chandel

Copyright () 2012 Jie Lu et al. This is an open access article distributed under the Creative Commons Attribution License, which permits unrestricted use, distribution, and reproduction in any medium, provided the original work is properly cited.

\begin{abstract}
Reed is a widespread-growing, inexpensive, and readily available lignocellulosic material source in northeast China. The objective of this study is to evaluate the liquid hot water (LHW) pretreatment efficiency of reed based on the enzymatic digestibility and ethanol fermentability of water-insoluble solids (WISs) from reed after the LHW pretreatment. Several variables in the LHW pretreatment and enzymatic hydrolysis process were optimized. The conversion of glucan to glucose and glucose concentrations are considered as response variables in different conditions. The optimum conditions for the LHW pretreatment of reed area temperature of $180^{\circ} \mathrm{C}$ for $20 \mathrm{~min}$ and a solid-to-liquid ratio of $1: 10$. These optimum conditions for the LHW pretreatment of reed resulted in a cellulose conversion rate of $82.59 \%$ in the subsequent enzymatic hydrolysis at $50^{\circ} \mathrm{C}$ for $72 \mathrm{~h}$ with a cellulase loading of 30 filter paper unit per gram of oven-dried WIS. Increasing the pretreatment temperature resulted in a higher enzymatic digestibility of the WIS from reed. Separate hydrolysis and fermentation of WIS showed that the conversion of glucan to ethanol reached $99.5 \%$ of the theoretical yield. The LHW pretreatment of reed is a suitable method to acquire a high recovery of fermentable sugars and high ethanol conversion yield.
\end{abstract}

\section{Introduction}

Lignocellulosic material (LCM) is an abundant, natural, and renewable carbon source for biofuel production. For a long time, studies have been performed to enhance the LCM enzymatic hydrolysis for the efficient conversion of cellulose to ethanol [1]. LCM has very strong resistance to enzymatic degradation such that LCM must be pretreated first to make cellulose degradation by cellulase easier and to improve the cellulose conversion in LCMs. In LCM bioconversion, pretreatment is one of the most expensive processing operations. Pretreatment can improve efficiency and reduce costs through research and development [2-7]. One of the most promising pretreatment processes for LCM is liquid hot water (LHW) pretreatment. LHW pretreatment enhances LCM digestibility, sugar extraction, and pentosan recovery. LHW pretreatment can remove up to $80 \%$ of the hemicellulose and enhances the enzymatic digestibility of pretreated material in herbaceous feedstocks [8], sugarcane bagasse [9], and wheat straw [10-16].

Reed is an abundant and inexpensive lignocellulosic raw material that can be found throughout northeastern China. According to statistics, the reed output all over the world was about $>70$ million tons, especially in Asia and Europe. In China, the planting areas for reed are over 10 million $\mathrm{mu}$, and the reed output reaches 3 million tons. The region with the greatest reed output is Panjin, Liaoning province, China. The Panjin reed field, which covers an area of 1.2 million $\mathrm{mu}$, is the largest reed-producing region in the world today. Five hundred thousand tons of reed are produced in the fields every year. Reed has been used in the papermaking industry for years as a good raw material because of its high cellulose content and good fiber properties. Nevertheless, studies on bioethanol production are few. Reed may be used as an alternative raw material for ethanol production. In this study, the LHW pretreatment of reed and the enzymatic hydrolysis 
of pretreated reed were investigated to determine its potential application for ethanol production by a bioconversion process. The pretreatment and enzymatic hydrolysis conditions were optimized to obtain a high conversion of cellulose to ethanol, and to enhance the enzymatic digestibility of reed, to obtain a high glucose yield. Ethanol fermentation was also conducted by separate hydrolysis and fermentation (SHF) and simultaneous saccharification and fermentation (SSF) processes using the pretreated reed as a glucose source to determine the feasibility of using reed in bioethanol production.

\section{Materials and Methods}

2.1. Materials. Reed, which has a moisture content of $11.67 \%$, was provided by the Yingkou papermaking mill, Yingkou, Liaoning province, China. The reed was milled to a particle size of 40 mesh to 60 mesh by using a laboratory ball mill (Taijihuan Nanometer Limited Company, Qinhuangdao, China) and was stored in a plastic bag until it was used in the experiments. Before the LHW pretreatment, the chemical compositions of reed were determined.

The commercial cellulase used in the enzymatic hydrolysis was purchased from the Imperial JADE Biotechnology Co., Ltd., Ningxia, China. The cellulase derived from Trichoderma longibrachiatum and the filter paper activity was assayed [17].

The yeast Saccharomyces cerevisiae was purchased from the Angel Yeast Co., Ltd., China. Before using it for fermentation, the yeast was activated. About $1 \mathrm{~g}$ of dry yeast was added to $20 \mathrm{~mL}$ of $5 \%$ sterilized glucose solution, activated at $38^{\circ} \mathrm{C}$ for $1 \mathrm{~h}$, cooled from $28^{\circ} \mathrm{C}$ to $30^{\circ} \mathrm{C}$, and then used in the experiment. The yeast concentration was approximately $10^{8}$ cells $/ \mathrm{mL}$.

2.2. LHW Pretreatment. The LHW pretreatment was conducted in a $15 \mathrm{~L}$ digester with four small tanks (mechanical mill of the Shanxi University of Science and Technology, China). About $40 \mathrm{~g}$ of reed and a given volume deionized water were loaded in the small tanks. The pretreatment temperature was controlled at $170^{\circ} \mathrm{C}, 180^{\circ} \mathrm{C}, 190^{\circ} \mathrm{C}, 200^{\circ} \mathrm{C}$, and $210^{\circ} \mathrm{C}$. The pretreatment time was set at either $20 \mathrm{~min}$ or $40 \mathrm{~min}$. After pretreatment, the water-insoluble solids (WISs) and the reed prehydrolyzates were separated by filtration with the Büchner funnel. The WISs were washed with deionized water to obtain a $\mathrm{pH}$ of approximately 7 . The WISs were used for subsequent enzymatic hydrolysis and ethanol fermentation.

2.3. Enzymatic Hydrolysis. Enzymatic hydrolysis of the washed WISs was performed at $36^{\circ} \mathrm{C}$ or $50^{\circ} \mathrm{C}$ for $72 \mathrm{~h}$ in $100 \mathrm{~mL}$ Erlenmeyer flasks. Each flask contained $20 \mathrm{~mL}$ to $50 \mathrm{~mL}$ of $0.05 \mathrm{M}$ sodium citrate buffer $(\mathrm{pH} 4.8)$ and had a solid-to-liquid ratio of 1:50 weight per volume (W/V) of WIS. The enzyme loading was 10 to 30 filter paper unit (FPU) per gram of oven-dried WIS. The samples were collected at $1,5,9,12,24,36,48$, and $72 \mathrm{~h}$ for glucose concentration determination. All enzymatic hydrolysis experiments were performed in duplicates, and the average results were determined.

2.4. Ethanol Fermentation. Separate hydrolysis and fermentation (SHF) was performed to check the fermentability of pretreated reed. The WIS from the pretreatment experiments (at $180^{\circ} \mathrm{C}$ and $210^{\circ} \mathrm{C}$ for $20 \mathrm{~min}$ each) was used as the substrate. About $100 \mathrm{~mL}$ of the enzymatic hydrolysis liquor and some nutrients, namely, $3 \mathrm{~g} / \mathrm{L}$ yeast extract, $5 \mathrm{~g} / \mathrm{L}$ peptone, $25 \mathrm{~g} / \mathrm{L} \mathrm{KH}_{2} \mathrm{PO}_{4}, 0.3 \mathrm{~g} / \mathrm{L} \mathrm{MgCl}_{2}$, and $0.25 \mathrm{~g} / \mathrm{L} \mathrm{CaCl}$, were added into $250 \mathrm{~mL}$ Erlenmeyer flasks. The total liquid volume was $100 \mathrm{~mL}$. The solid concentration was 6\% (by WIS weight) during the hydrolysis. The resulting slurry was inoculated with $1 \mathrm{~mL}$ of activated yeast. The flasks were autoclaved at $121^{\circ} \mathrm{C}$ for $20 \mathrm{~min}$. The experiments were performed in duplicates in a constant-temperature incubator at $36^{\circ} \mathrm{C}$ for $72 \mathrm{~h}$. The flasks were sealed with rubber stoppers and equipped with cannulas to remove the generated carbon dioxide. The cannulas were inserted into a container filled with water. The simultaneous saccharification and fermentation (SSF) experiment was conducted based on the SSF protocol by the National Renewable Energy Laboratory (NREL) LAP-008 [18]. The initial WIS concentration was $8 \%$.

All experiments were performed in duplicates in the same conditions, and the average values were reported.

2.5. Analysis Methods. The contents of xylan, Klason lignin, ash, and benzene-alcohol $(2: 1)$ extractives were determined using the Chinese National Standard methods, namely, the GB/T2677.9-1994, GB/T2677.8-1994, GB/T2677.3-1993, and GB/T2677.6-1994, respectively. The acid-soluble lignin content was determined using the method described in GB/T10337-1989. The glucan content was determined according to NREL methods [19]. The glucose content and ethanol were determined using the SBA-40E Biological Sensing Analyzer (Biology Institute of the Shandong Academy of Sciences, Jinan, China). The glucan content was calculated using formula (1):

$$
\text { Glucan content }(\%)=\frac{(\text { glucose } * 0.087 * 0.9)}{m} * 100 \%,
$$

where glucose is glucose concentration $(\mathrm{g} / \mathrm{L}) ; m$ is mass of oven-dried WIS (g); 0.087 iss volume of acid hydrolysis liquid (L); 0.9 is conversion factor for glucose to glucan.

The conversion of cellulose to glucose in the enzymatic hydrolysis was determined by the ratio of the glucose concentration that was released during enzymatic hydrolysis to the total glucose in the substrate and was calculated using formula:

$$
\begin{aligned}
& \text { Conversion of cellulose to glucose (\%) } \\
& =\frac{\text { glucose } * V * 0.9}{\text { glucan content } * m} * 100 \%,
\end{aligned}
$$

where glucose is glucose concentration in the enzymatic hydrolysis liquor $(\mathrm{g} / \mathrm{L}) ; V$ is volume of enzymatic hydrolysis liquor (L); $m$ is mass of oven-dried WIS (g). 
TABLE 1: Chemical compositions of reed and other biomass sources (\%, by dry weight).

\begin{tabular}{lcccc}
\hline Compositions & Reed & Rice Straw & Corn stover & Wheat straw \\
\hline Glucan & 40.5 & 34.6 & 36.1 & 37.8 \\
Xylan & 25.9 & 21.3 & 21.4 & 22.8 \\
Klason lignin & 16.2 & 9.6 & 17.2 & 16.3 \\
Acid-soluble lignin & 2.0 & 3.4 & - & 1.8 \\
Ash & 3.6 & 14.5 & 7.1 & 6.3 \\
\hline
\end{tabular}

For SHF and SSF of WIS, the conversion of cellulose to ethanol was calculated using formula (3):

Conversion of cellulose to ethanol (\%)

$$
=\frac{[\mathrm{EtOH}]}{(f * \text { biomass } * 1.111 * 0.51)} * 100 \%
$$

where $[\mathrm{EtOH}]$ is ethanol concentration at the end of the fermentation minus any ethanol produced from the enzyme and medium $(\mathrm{g} / \mathrm{L}) ; f$ is cellulose fraction of dry biomass $(\mathrm{g} / \mathrm{g})$; Biomass is dry biomass concentration at the beginning of the fermentation $(\mathrm{g} / \mathrm{L}) ; 0.51$ is conversion factor for glucose to ethanol based on stoichiometric biochemistry of yeast; 1.111 is conversion factor of cellulose to equivalent glucose.

\section{Results and Discussion}

3.1. Chemical Composition of Reed. The chemical compositions of reed used in this study were determined and shown in Table 1. Table 1 also shows the chemical components of other agricultural residues, such as rice straw [20], corn stover [21], and wheat straw [10], which were used in the bioethanol investigation in the present study. Glucan and xylan are the main components of reed, both of which accounted for $66.4 \%$ of dry weight of the raw material. Compared with the other raw materials that were generally used in bioethanol investigations, the reed contained more glucan and xylan, which indicated that more fermentable sugars could be produced via enzymatic hydrolysis and that reed can be used in bioethanol production. The lignin component of the raw materials had a significant function in the enzymatic saccharification process [22]. This lignin component can inhibit the enzymatic hydrolysis of cellulose by adsorbing cellulase in the system and/or limiting the enzyme accessibility to cellulose. Klason lignin accounts for $16.2 \%$ of the reed. Similar to that of corn stover and wheat straw, this value is higher than that of rice straw, which indicated that the lignin effect on enzymatic hydrolysis might be similar to reed, corn stover, and wheat straw (only for their lignin content). The reed contains less ash than other raw materials, which indicates that it has less effect on cellulase activity in the hydrolysis system and produces more pure products such as fermentable sugars. Thus, reed is a promising source for bioethanol production.
TABLE 2: Glucan contents of WIS in different pretreatment temperature and time (\%, by weight of WIS).

\begin{tabular}{lcc}
\hline \multirow{2}{*}{ Temperature $\left({ }^{\circ} \mathrm{C}\right)$} & \multicolumn{2}{c}{ Pretreatment time } \\
\hline 170 & $20 \mathrm{~min}$ & $40 \mathrm{~min}$ \\
180 & 45.47 & 51.16 \\
190 & 53.98 & 55.55 \\
200 & 54.31 & 57.46 \\
210 & 54.29 & 56.81 \\
\hline
\end{tabular}

\subsection{Effect of Pretreatment Conditions on Enzymatic Hydrolysis of Reed WIS}

3.2.1. Effect of Pretreatment on Temperature and Time. The pretreatment conditions were selected based on whether they could modify the structural and chemical characteristics of the biomass that limited the enzyme availability to cellulose in cell-wall microfibrils [23]. Several reports have shown that sample pretreatment at higher temperatures resulted in a higher enzymatic digestibility than the untreated sample and could yield a higher glucose concentration upon enzymatic hydrolysis [24]. In the study, enzymatic hydrolysis was also conducted on unpretreated raw material for comparison purposes. The glucan contents of each WIS after LHW pretreatment at different temperatures and time points are summarized in Table 2. The glucan contents of all WISs were higher than that of the raw reed at $40.5 \%$ (Table 1). The glucan contents of all WISs ranged from $45 \%$ to $58 \%$ of WIS, and this value depends on the pretreatment temperature and time. The glucan content increased with increasing pretreatment time. Meanwhile, the glucan content also increased with increasing pretreatment temperature. The highest glucose content was obtained at $210^{\circ} \mathrm{C}$ for 40 min because the water-soluble components in the raw reed were solubilized. For example, lignin with low molecular weight and extractives resulted in a fraction of glucanenriched WIS production with increasing temperature and time. The reed hemicellulose component was also partly degraded and dissolved, which also led to the increase in WIS glucan content. The enzymatic hydrolysis profile of WIS-pretreated reed at different pretreatment temperature and time is shown in Figure 1. The enzymatic digestibility of each WIS was different. The conversion of cellulose to glucose rapidly increased at the beginning of the enzymatic hydrolysis process and then slowly declined, as previously reported $[25,26]$. The untreated raw reed was difficult 


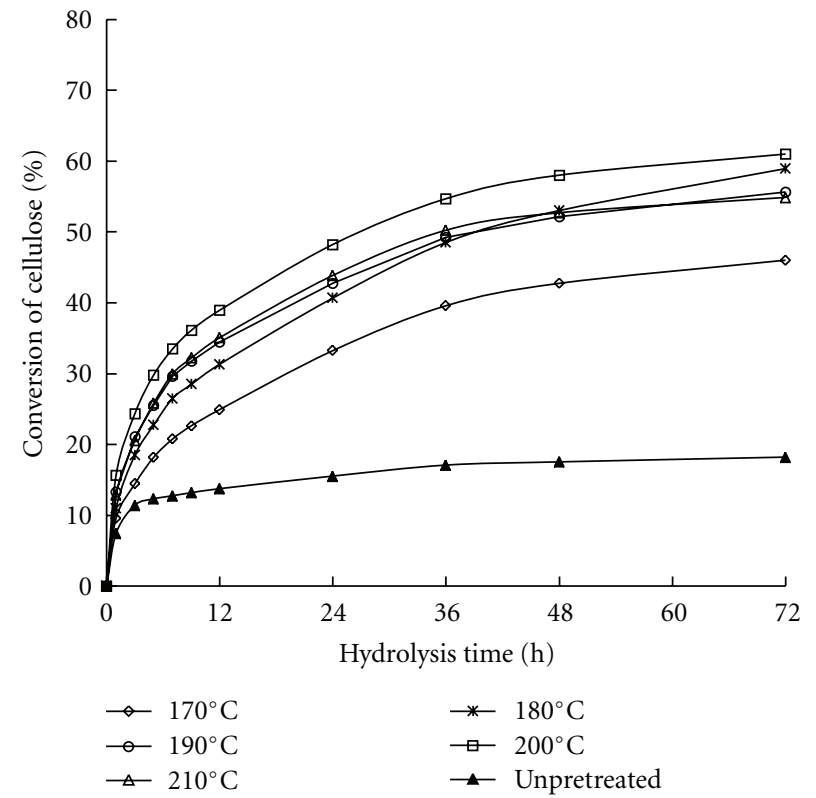

(a) Pretreatment time of $20 \mathrm{~min}$

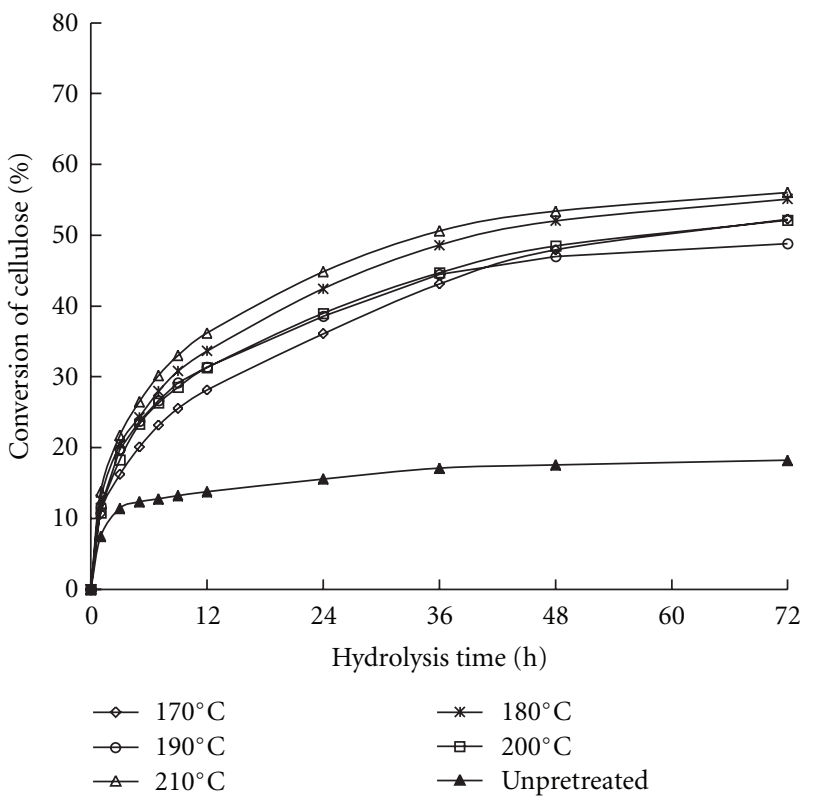

(b) Pretreatment time of $40 \mathrm{~min}$

FIgURE 1: Conversion of cellulose to glucose in the enzymatic hydrolysis of WIS from LHW-pretreated reed, with different pretreatment temperatures and times. ${ }^{*}$ Enzymatic hydrolysis conditions: $15 \mathrm{FPU} / \mathrm{g}$ oven-dried WIS, $\mathrm{pH} 4.8$, solid-to-liquid ratio $1: 50(\mathrm{w} / \mathrm{v})$, and $50^{\circ} \mathrm{C}$ for $72 \mathrm{~h}$.

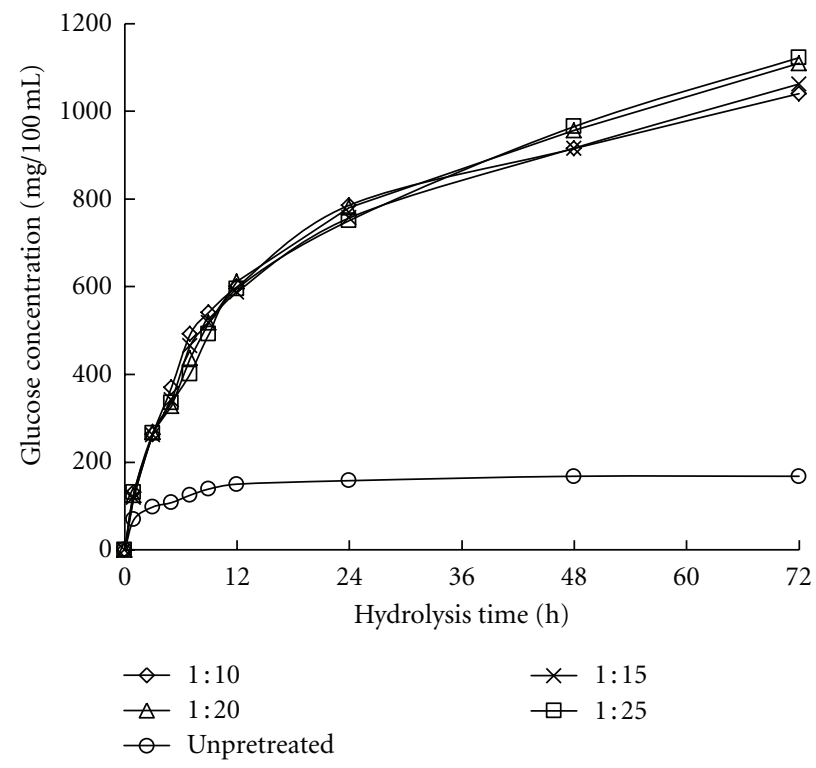

(a) Glucose release from WIS in the enzymatic hydrolysis

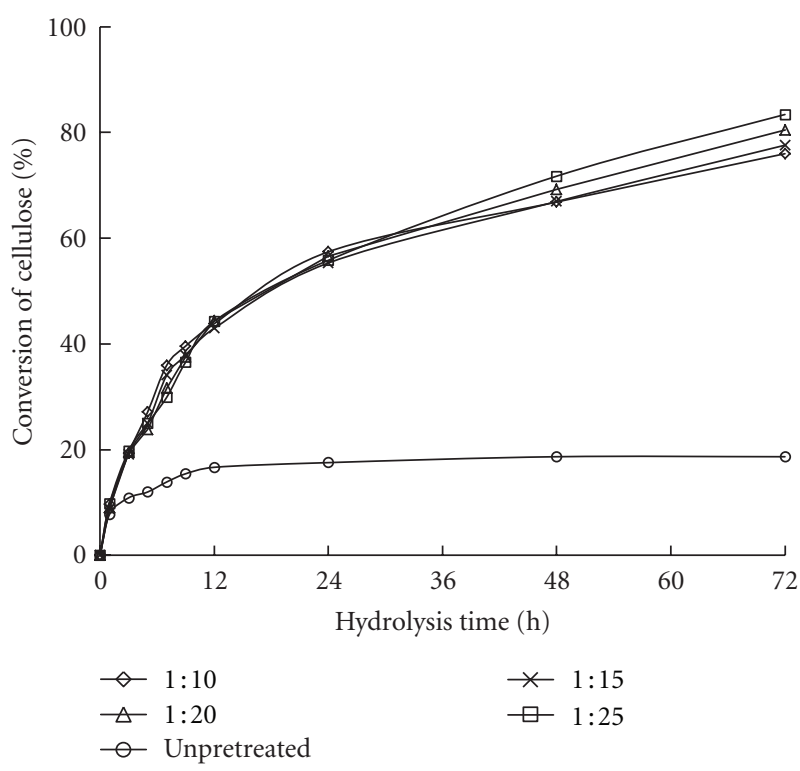

(b) Conversion of cellulose of WIS

FIGURE 2: Effect of solid-to-liquid ratio on enzymatic hydrolysis of the WIS from the pretreated reed. ${ }^{*} \mathrm{LHW}$ pretreatment: $180^{\circ} \mathrm{C}$ for 20 min. ** Enzymatic hydrolysis: $30 \mathrm{FPU} / \mathrm{g}$ oven-dried WIS, $\mathrm{pH} 4.8$, at $50^{\circ} \mathrm{C}$.

to hydrolyze enzymatically. The maximum conversion of cellulose to glucose was only $18.22 \%$ at $72 \mathrm{~h}$ of enzymatic hydrolysis. However, in WIS from the pretreated samples, the cellulose conversion in the enzymatic hydrolysis ranged from $47 \%$ to $64 \%$ based on the pretreatment severity. The increase in the WIS enzymatic digestibility may be due to the ability of LHW pretreatment to increase the surface area of the raw material samples, which leads to sufficient contact between the cellulase and the substrate. Thus, the glucose release increases. The cellulose conversion decreased from $82.59 \%$ to $56.70 \%$ at $72 \mathrm{~h}$ when the pretreatment time was prolonged from $20 \mathrm{~min}$ to $40 \mathrm{~min}$ at $180^{\circ} \mathrm{C}$. This decrease in cellulose conversion indicated that a prolonged pretreatment time does not improve WIS enzymatic hydrolysis. Figure 1 


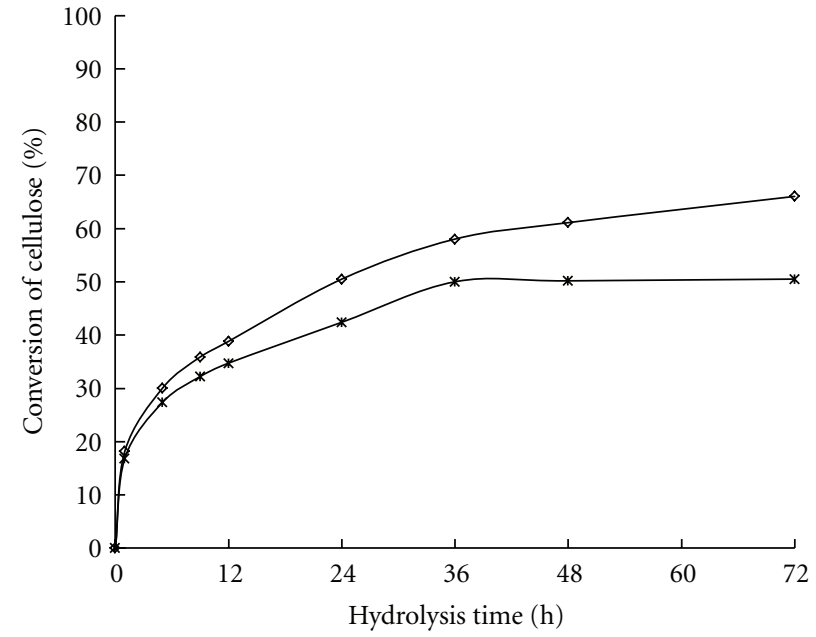

$\rightarrow$ HAC-NaAC

* Sulfuric acid

(a) LHW pretreatment at $180^{\circ} \mathrm{C}$

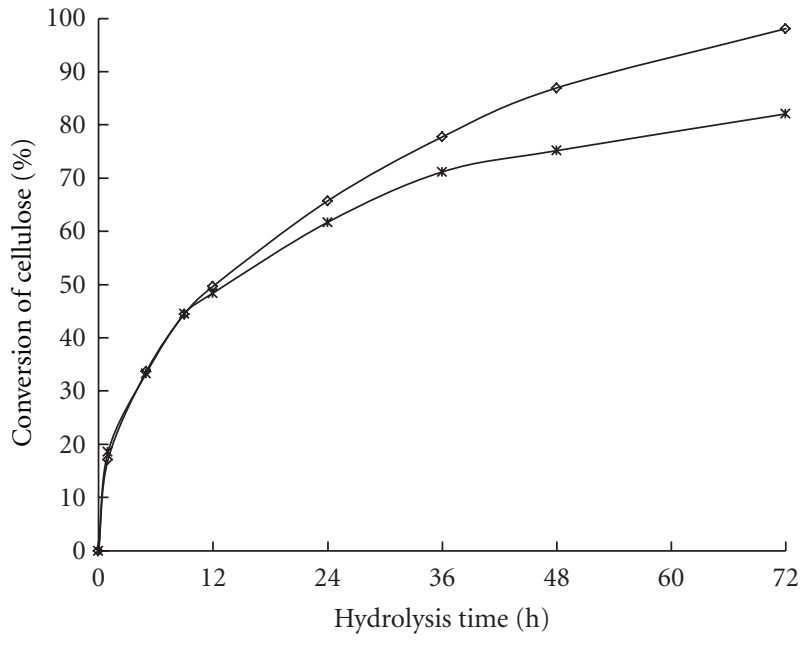

$\rightarrow$ HAC-NaAC

$\rightarrow$ Sulfuric acid

(b) $\mathrm{LHW}$ pretreatment at $210^{\circ} \mathrm{C}$

Figure 3: Enzymatic hydrolysis of WIS from LWH-pretreated reed at $180^{\circ} \mathrm{C}$ and $210^{\circ} \mathrm{C}$ by using two types of pH adjustment in the hydrolysis system. *Enzymatic hydrolysis: $30 \mathrm{FPU} / \mathrm{g}$ oven-dried WIS at $36^{\circ} \mathrm{C}$.

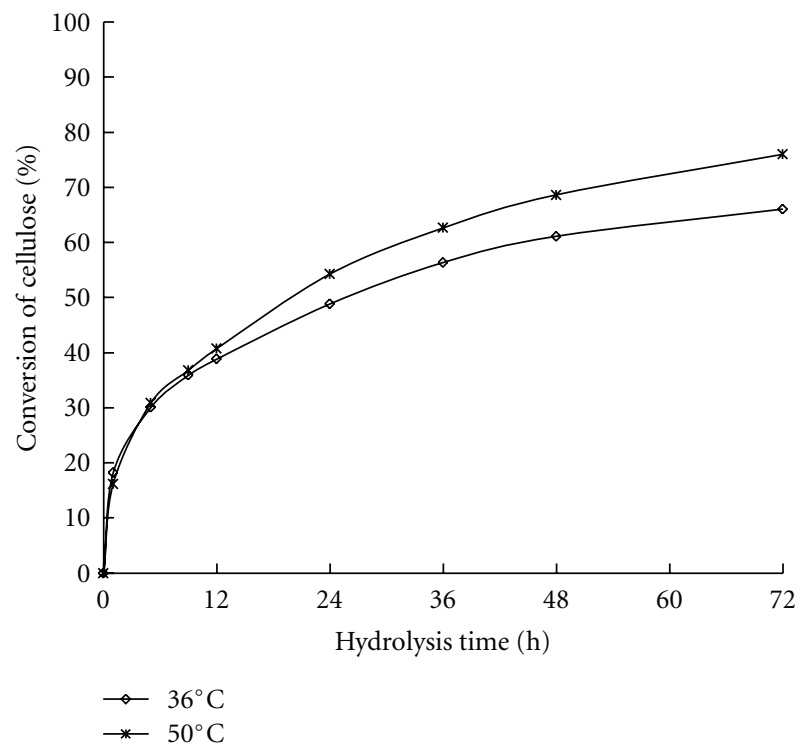

(a) Conversion of WIS from reed pretreated at $180^{\circ} \mathrm{C}$

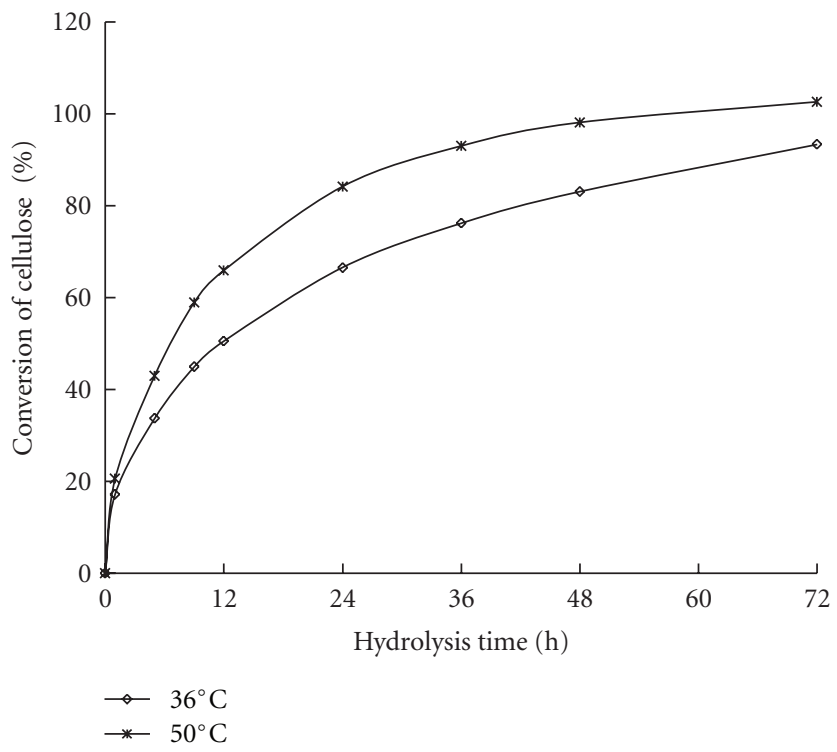

(b) Conversion of WIS from reed pretreated at $210^{\circ} \mathrm{C}$

Figure 4: Temperature effects on the WIS conversion from reed in the LHW pretreatment at $180^{\circ} \mathrm{C}$ and $210^{\circ} \mathrm{C}$ for 20 min. ${ }^{*}$ Enzymatic hydrolysis: $30 \mathrm{FPU} / \mathrm{g}$ oven-dried WIS at $\mathrm{pH} 4.8$.

also shows that temperature had no significant effects on WIS enzymatic hydrolysis at a temperature of $>180^{\circ} \mathrm{C}$. Hightemperature and prolonged LHW pretreatment also led to more polysaccharide degradation and loss, which decreased cellulose yield. Therefore, LHW pretreatment at $180^{\circ} \mathrm{C}$ for $20 \mathrm{~min}$ was suitable for the reed. Moreover, a cellulose conversion of $82.59 \%$ at $72 \mathrm{~h}$ of enzymatic hydrolysis was obtained in the LHW pretreatment in the same conditions.
3.2.2. Effect of Solid-to-Liquid Ratio in LHW Pretreatment. The solid-to-liquid ratio is the ratio between the ovendried WIS quality and the entire liquid volume in the LHW pretreatment. When the reed quantity was kept constant, a higher solid-to-liquid ratio led to a lower substrate concentration, which further decreased the end-product inhibition. Reducing the solid-to-liquid ratio would decrease process cost by lowering the reactor size and the amount 


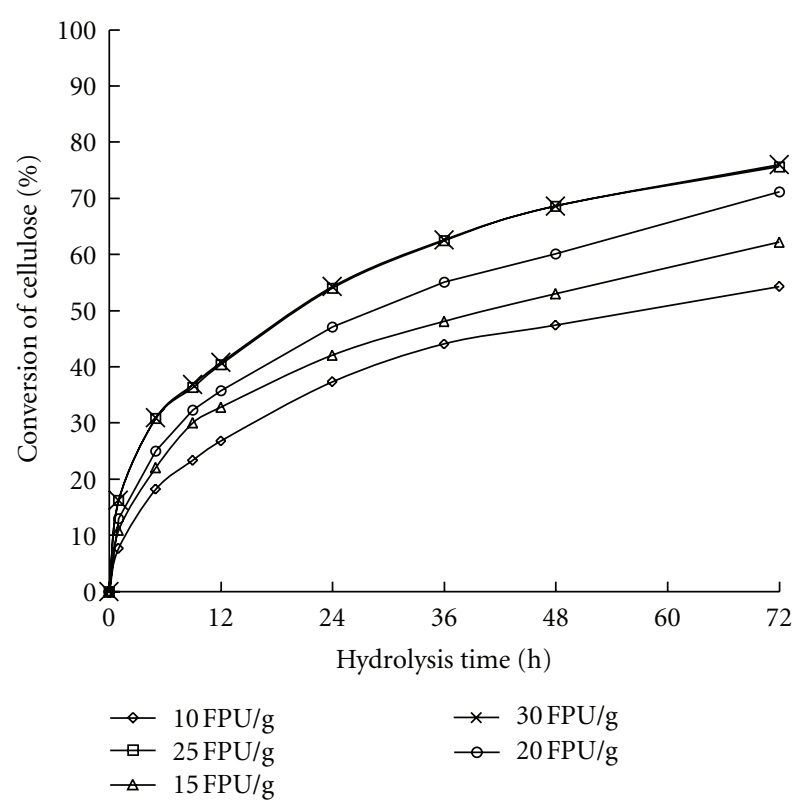

(a) Conversion of WIS from reed pretreated at $180^{\circ} \mathrm{C}$

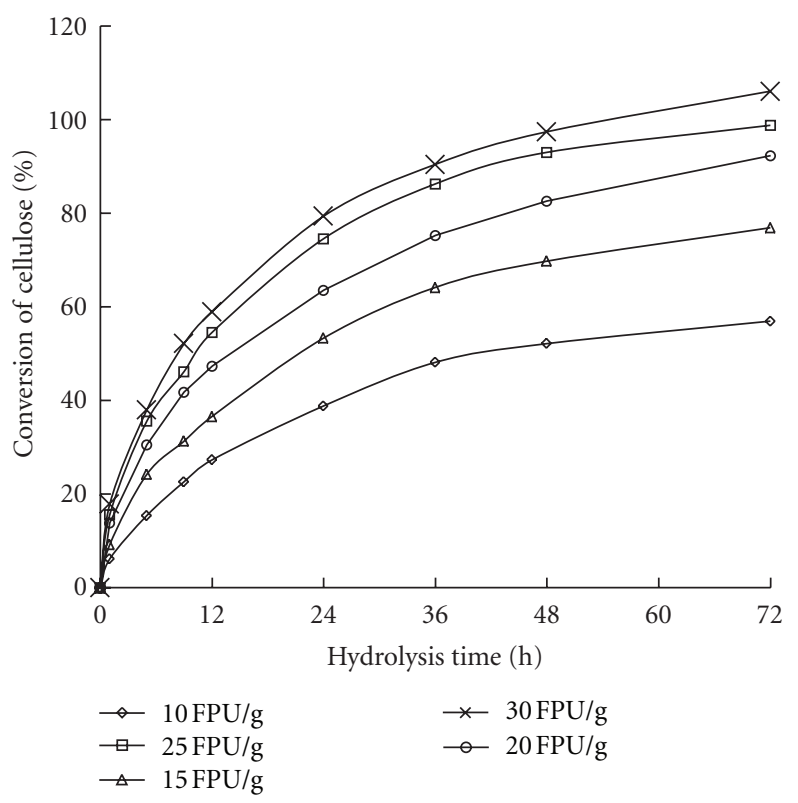

(b) Conversion of WIS from reed pretreated at $210^{\circ} \mathrm{C}$

Figure 5: Enzymatic hydrolysis of WIS from reed in the LHW pretreatment at $180^{\circ} \mathrm{C}$ and $210^{\circ} \mathrm{C}$ with respect to different cellulase loadings.

of heat requirement during the pretreatment. When the solid-to-liquid ratio was increased from $1: 10$ to $1: 25(\mathrm{w} / \mathrm{v})$ in the LHW pretreatment at $180^{\circ} \mathrm{C}$, the glucose release slightly increases in the later enzymatic hydrolysis period. For example, the conversion of cellulose to glucose at $72 \mathrm{~h}$ of enzymatic hydrolysis increased from $75.97 \%$ to $83.39 \%$ with only a difference of $7.42 \%$ after 48 h (Figure 2). This increase in the conversion of cellulose to glucose showed that the solid-to-liquid ratio had little effect on the enzymatic digestibility of WIS from reed. However, keeping the reaction system homogeneous is difficult because the liquid present in the reaction system is less when the solid-to-liquid ratio is lower than $1: 10$. Therefore, a solid-to-liquid ratio of $1: 10$ was used for the LHW pretreatment of reed.

\subsection{Optimization of Enzymatic Hydrolysis of the Reed WIS}

3.3.1. Effect of Adjusting pH on the Enzymatic Hydrolysis of WIS. A suitable $\mathrm{pH}$ in the enzymatic hydrolysis system is beneficial to the cellulase function on the substrate. The systemic $\mathrm{pH}$ has to be adjusted to improve cellulase effectiveness in hydrolysis. In this study, two different methods were used for adjusting and controlling the $\mathrm{pH}$. One method involves the use of sodium citrate buffer $(\mathrm{pH} 4.8,0.05 \mathrm{M})$, and the other method involves the use of $\mathrm{H}_{2} \mathrm{SO}_{4}$. Figure 3 shows that the use of sodium citrate buffer to adjust the $\mathrm{pH}$ was better than using $\mathrm{H}_{2} \mathrm{SO}_{4}$ for the cellulase function on the WIS in the LHW-pretreated reed at $180^{\circ} \mathrm{C}$ and $210^{\circ} \mathrm{C}$. A higher cellulose conversion was obtained when the sodium citrate buffer was used to adjust the $\mathrm{pH}$, which indicated that this buffer was effective in controlling the $\mathrm{pH}$ of the enzymatic hydrolysis process and in improving the cellulase effectiveness.
3.3.2. Effect of Enzymatic Temperature on the Enzymatic Hydrolysis of Reed WIS. The enzymatic temperature affects cellulase activity and effectiveness in enzymatic hydrolysis. The temperature in the enzymatic hydrolysis is generally kept at $50^{\circ} \mathrm{C}$, which is a suitable temperature for the cellulase activity. However, the yeast fermentation temperature is $36^{\circ} \mathrm{C}$. Two different enzymatic temperatures were used for the enzymatic hydrolysis of WIS to compare the effects of different enzymatic temperatures on WIS enzymatic digestibility. Figure 4 shows the comparisons of the cellulose conversion after enzymatic hydrolysis between two WISs from $\mathrm{LWH}$-pretreated reed at $180^{\circ} \mathrm{C}$ and $210^{\circ} \mathrm{C}$, respectively. The cellulose conversion after enzymatic hydrolysis at $36^{\circ} \mathrm{C}$ was slightly lower than that at $50^{\circ} \mathrm{C}$. Therefore, a hydrolysis temperature of $50^{\circ} \mathrm{C}$ may be used in the bioethanol enzymatic hydrolysis via the SHF process. Nevertheless, a temperature of $36^{\circ} \mathrm{C}$ was considered suitable for yeast fermentation, which was beneficial to the succeeding SSF.

\subsubsection{Effect of Cellulase Loadings on the Enzymatic Hydrolysis} of Reed WIS. Aside from the enzymatic temperature and $\mathrm{pH}$, cellulase loading is also an important factor for the enzymatic hydrolysis of cellulosic substrates. Increasing the cellulase loading generally resulted in an increase in glucose release and cellulose conversion. The enzymatic hydrolysis curves of the WIS in reed after the LHW pretreatment with respect to several cellulase loadings are shown in Figure 5. Cellulase loading had a significant effect on cellulose conversion in WIS by enzymatic hydrolysis. When the cellulase loading was increased from $10 \mathrm{FPU} / \mathrm{g}$ oven-dried WIS to $25 \mathrm{FPU} / \mathrm{g}$ oven-dried WIS on pretreated reed at $180^{\circ} \mathrm{C}$ or $210^{\circ} \mathrm{C}$ for $20 \mathrm{~min}$, the enzymatic digestibility of reed WIS was 


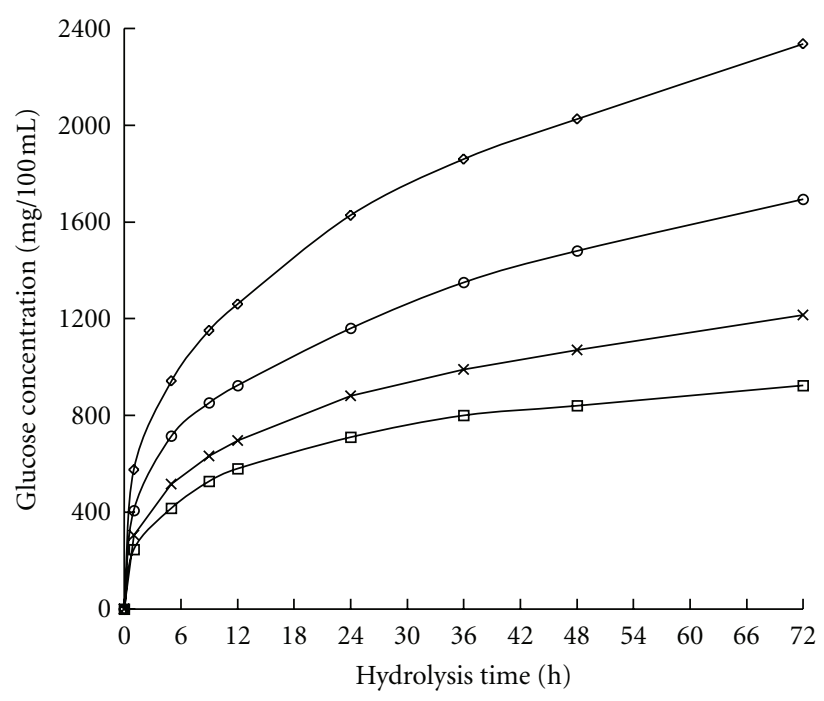

(a) Glucose release of WIS from reed pretreated at $180^{\circ} \mathrm{C}$

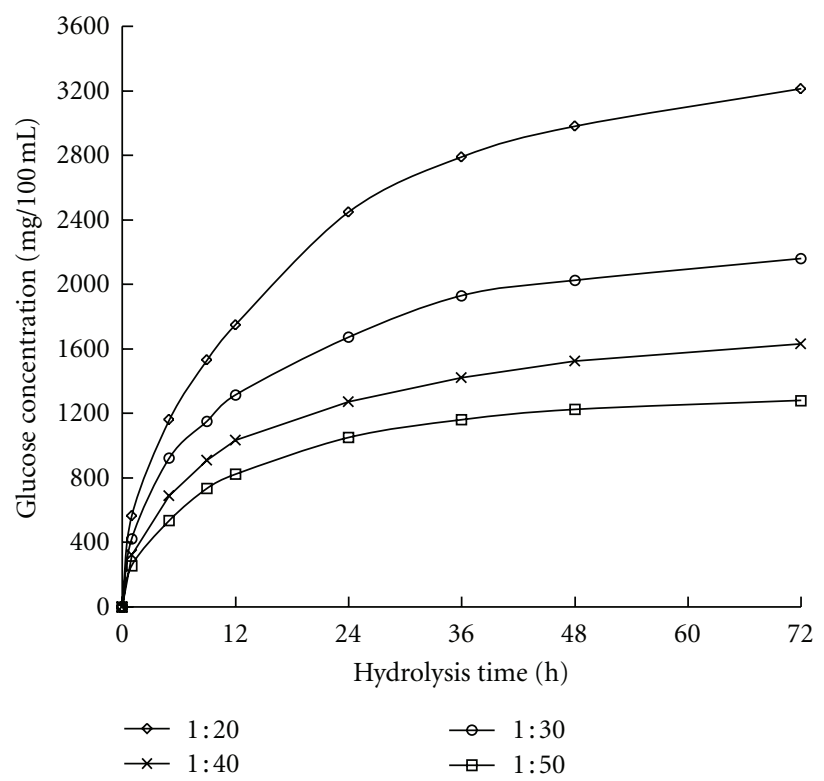

(c) Glucose release of WIS from reed pretreated at $210^{\circ} \mathrm{C}$

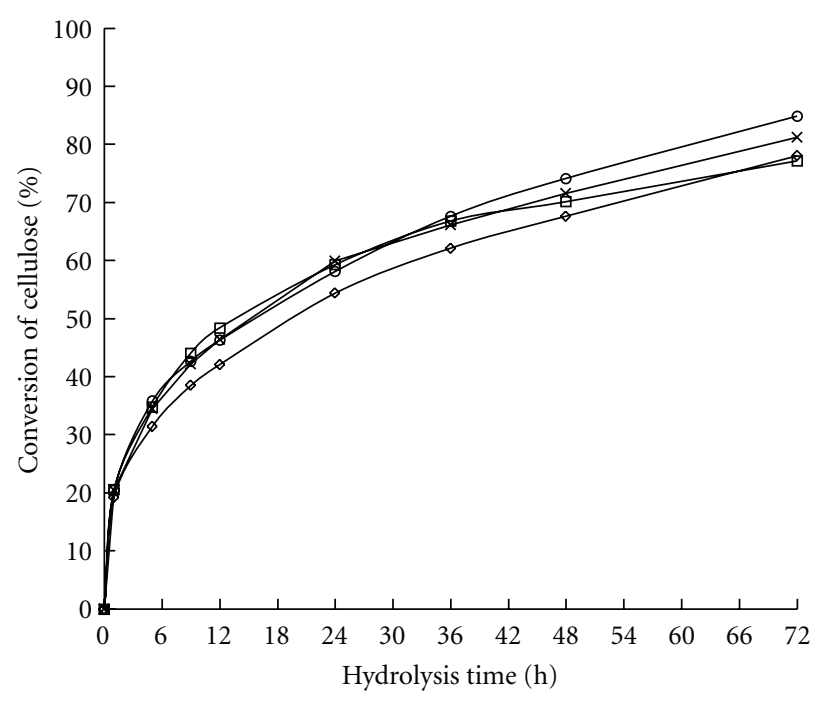

(b) Cnversion of WIS from reed pretreated at $180^{\circ} \mathrm{C}$

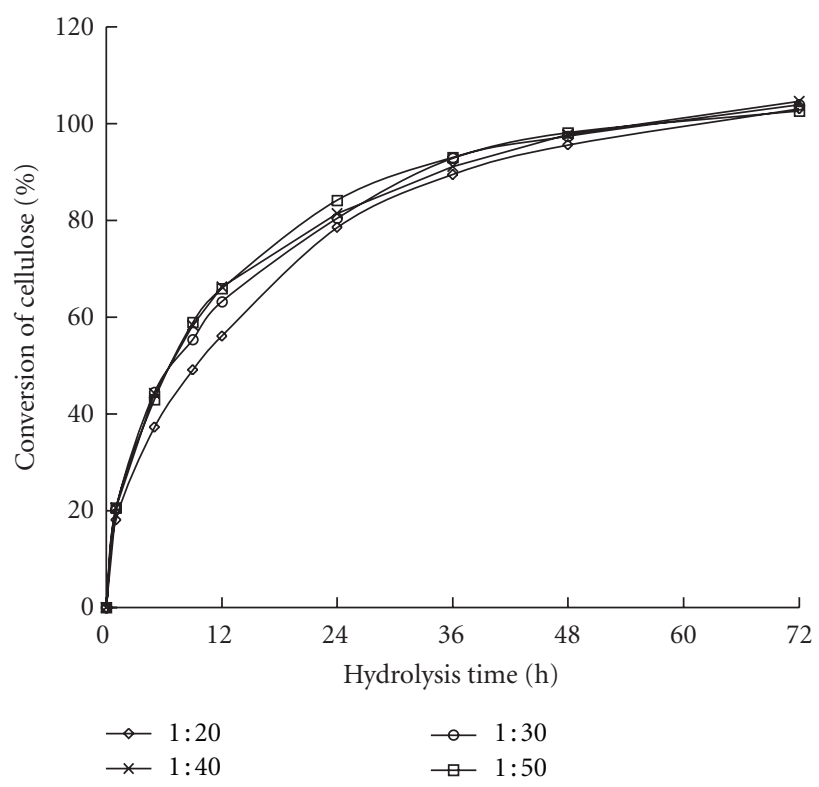

(d) Conversion of WIS from reed pretreated at $210^{\circ} \mathrm{C}$

FIGURE 6: Enzymatic hydrolysis of WIS from reed pretreated at $180^{\circ} \mathrm{C}$ and $210^{\circ} \mathrm{C}$ with respect to different solid-to-liquid ratios in enzymatic hydrolysis.

greatly improved. However, the increase in cellulase loading from $25 \mathrm{FPU} / \mathrm{g}$ to $30 \mathrm{FPU} / \mathrm{g}$ slightly affected the cellulose conversion in the WIS in reed. Figure 5 also shows that cellulose conversion in WIS from reed pretreated at $210^{\circ} \mathrm{C}$ was higher than that in WIS from reed pretreated at $180^{\circ} \mathrm{C}$ in the same enzymatic hydrolysis conditions. A higher cellulose conversion in WIS from reed pretreated at $210^{\circ} \mathrm{C}$ indicated that a higher pretreatment temperature improves the enzymatic digestibility of reed and increases the glucose release during enzymatic hydrolysis.

3.3.4. Effect of Solid-to-Liquid Ratio on the Enzymatic Hydrol$y$ sis. A high glucose concentration is necessary to obtain high ethanol concentration by fermentation, which results in a decrease in the production cost, such as ethanol distillation cost. Decreasing the solid-to-liquid ratios during the enzymatic hydrolysis of a cellulosic substrate may increase glucose consistency. Nevertheless, very low solid-to-liquid ratio indicates a very high initial solid concentration, which causes difficulty in uniformly mixing the enzyme liquid and the WIS because the amount of liquid in the system is reduced. The trends of change in the cellulose conversion are illustrated in Figure 6.The glucose concentration in the hydrolyzates increased when the solid-to-liquid ratio decreased in the enzymatic hydrolysis of WIS from reed that was pretreated at both $180^{\circ} \mathrm{C}$ and $210^{\circ} \mathrm{C}$ (i.e., $1: 50<1: 40<1: 30<1: 20$; Figures $6(\mathrm{a})$ and $6(\mathrm{c}))$. The highest glucose concentrations $\left(2326 \mathrm{mg} / 100 \mathrm{~mL}\right.$ at $180^{\circ} \mathrm{C}$ and $3213 \mathrm{mg} / 100 \mathrm{~mL}$ at $210^{\circ} \mathrm{C}$ ) 
TABLE 3: Ethanol fermentation of WIS after LHW pretreatment.

\begin{tabular}{lcccccc}
\hline Substrates & $\begin{array}{c}\text { Ethanol } \\
\text { concentrations } \\
(\mathrm{g} / \mathrm{L})\end{array}$ & $\begin{array}{c}\text { Sesidual glucose } \\
(\mathrm{g} / \mathrm{L})\end{array}$ & $\begin{array}{c}\text { Conversion of } \\
\text { cellulose to } \\
\text { ethanol }(\%)\end{array}$ & $\begin{array}{c}\text { Ethanol } \\
\text { concentrations } \\
(\mathrm{g} / \mathrm{L})\end{array}$ & $\begin{array}{c}\text { Residual glucose } \\
(\mathrm{g} / \mathrm{L})\end{array}$ & $\begin{array}{c}\text { Conversion of } \\
\text { cellulose to } \\
\text { ethanol }(\%)\end{array}$ \\
\hline Reed & 5.07 & 0.06 & 36.9 & 4.30 & 0.39 & 23.4 \\
Reed at $180^{\circ} \mathrm{C}$ for $20 \mathrm{~min}$ & 17.69 & 0.06 & 96.6 & 17.60 & 0.34 & 72.1 \\
Reed at $210^{\circ} \mathrm{C}$ for $20 \mathrm{~min}$ & 18.99 & 0.06 & 99.5 & 21.75 & 0.36 & 85.5 \\
\hline
\end{tabular}

were obtained at a solid-to-liquid ratio of $1: 20$ after $72 \mathrm{~h}$ of enzymatic hydrolysis. The lowest glucose concentrations $\left(924 \mathrm{mg} / 100 \mathrm{~mL}\right.$ at $180^{\circ} \mathrm{C}$ and $1280 \mathrm{mg} / 100 \mathrm{~mL}$ at $\left.210^{\circ} \mathrm{C}\right)$ were obtained at a solid-to-liquid ratio of $1: 50$ after $72 \mathrm{~h}$ of enzymatic hydrolysis. The difference between the highest and lowest glucose concentrations showed an increase of $60.3 \%$ at $180^{\circ} \mathrm{C}$ and $60.2 \%$ at $210^{\circ} \mathrm{C}$, respectively. However, the change in the solid-to-liquid ratio did not obviously affect the cellulose bioconversion (Figures 6(b) and 6(d)). Thus, the increase in the glucose concentration by decreasing the solid-to-liquid ratio in the enzymatic hydrolysis process was beneficial in the subsequent ethanol fermentation.

\subsection{Ethanol Fermentation of Reed WIS after LHW Pretreat-} ment. Ethanol production depends on the sugar yield and the mixture fermentability. The WIS obtained from different pretreatment conditions, namely, $180^{\circ} \mathrm{C}$ at $20 \mathrm{~min}$ and $210^{\circ} \mathrm{C}$ at $20 \mathrm{~min}$, were fermented by SHF and SSF methods by using special ethanol yeast to investigate the fermentability of the WIS from LWH-pretreated reed. Table 3 shows the ethanol fermentation results of WIS by SHF and SSF and the cellulose conversion to ethanol expressed as theoretical yield percentages based on (3). In SHF, the obtained ethanol concentrations reached $17.69 \mathrm{~g} / \mathrm{L}$ during pretreatment at $180^{\circ} \mathrm{C}$ and $18.99 \mathrm{~g} / \mathrm{L}$ during pretreatment at $210^{\circ} \mathrm{C}$ after $72 \mathrm{~h}$ of fermentation. The calculated ethanol conversion yield reached $96.6 \%$ at $180^{\circ} \mathrm{C}$ and $99.5 \%$ at $210^{\circ} \mathrm{C}$ of the theoretical yield. These calculated ethanol conversion yields indicated that the SHF process was a very efficient method for producing ethanol from LHW-pretreated reed. In SSF, the pretreated WIS fermentation was performed at an initial $\mathrm{pH}$ of 4.8 at $36^{\circ} \mathrm{C}$. The yeast strain at this temperature produced a maximum ethanol concentration from glucose, which was consistent with the results of previous SSF studies [27]. With $10 \%$ (volume per volume) inoculum, the highest conversion of cellulose to ethanol reached $85.5 \%$ for WIS from pretreated reed at $210^{\circ} \mathrm{C}$ for $20 \mathrm{~min}$. The experiments showed that WIS from LWH-pretreated reed has good fermentability, and LHW pretreatment can be used in bioethanol production.

\section{Conclusion}

Reed can be used as a substrate for ethanol production in northeast China. The LHW pretreatment significantly enhanced the enzymatic digestibility of reed. The optimum conditions of LHW pretreatment for reed were a temperature of $180^{\circ} \mathrm{C}$ for $20 \mathrm{~min}$ and a solid-to-liquid ratio of $1: 10$, which resulted in a cellulose conversion rate of $82.59 \%$ in the subsequent enzymatic hydrolysis at $50^{\circ} \mathrm{C}$ for $72 \mathrm{~h}$ with a cellulase loading of $30 \mathrm{FPU} / \mathrm{g}$ oven-dried WIS. After the LHW pretreatment, the conversion of glucan to ethanol in WIS from LWH-pretreated reed reached $99.5 \%$ of theoretical yield by the SHF process.

\section{Acknowledgments}

This study was financially supported by the National Key Basic Research Development Program (2011CB707401), the National Natural Science Foundation of China (nos. $31100440,21276143)$, and the International Science \& Technology Cooperation Program of China (2010DFA32560).

\section{References}

[1] A. T. W. M. Hendriks and G. Zeeman, "Pretreatments to enhance the digestibility of lignocellulosic biomass," Bioresource Technology, vol. 100, no. 1, pp. 10-18, 2009.

[2] L. R. Lynd, R. T. Elander, and C. E. Wyman, "Likely features and costs of mature biomass ethanol technology," Applied Biochemistry and Biotechnology A, vol. 57-58, pp. 741-761, 1996.

[3] D. Lee, A. H. C. Yu, K. K. Y. Wong, and J. N. Saddler, "Evaluation of the enzymatic susceptibility of cellulosic substrates using specific hydrolysis rates and enzyme adsorption," Applied Biochemistry and Biotechnology, vol. 45-46, no. 1, pp. 407-415, 1994.

[4] K. L. Kohlmann, A. Sarikaya, P. J. Westgate et al., "Enhanced enzyme activities on hydroated lignocellulosic substrates," in Enzymatic Degradation of Insoluble Carbohydrates, J. N. Saddler and M. H. Penner, Eds., pp. 237-255, ACS Publishing, 1995.

[5] M. R. Ladisch, N. Mosier, and R. Hendrickson, "Principles and economics of pretreating cellulose in water for ethanol production," Abstracts of Papers American Chemical Society, vol. 225, p. U85, 2003.

[6] N. S. Mosier, R. Hendrickson, G. Welch, R. Dreschel, B. Dien, and M. R. Ladisch, "Corn fiber pretreatment scale-up and evaluation in an industrial corn to ethanol facility," in Proceedings of the 25th Symposium on Biotechnology for Fuels and Chemicals, Breckenridge, Colo, USA, 2003, Paper 6A-04.

[7] N. Mosier, C. Wyman, B. Dale et al., "Features of promising technologies for pretreatment of lignocellulosic biomass," Bioresource Technology, vol. 96, no. 6, pp. 673-686, 2005.

[8] N. Mosier, R. Hendrickson, N. Ho, M. Sedlak, and M. R. Ladisch, "Optimization of $\mathrm{pH}$ controlled liquid hot water 
pretreatment of corn stover," Bioresource Technology, vol. 96, no. 18, pp. 1986-1993, 2005.

[9] M. Laser, D. Schulman, S. G. Allen, J. Lichwa, M. J. Antal, and L. R. Lynd, "A comparison of liquid hot water and steam pretreatments of sugar cane bagasse for bioconversion to ethanol," Bioresource Technology, vol. 81, no. 1, pp. 33-44, 2002.

[10] J. A. Pérez, I. Ballesteros, M. Ballesteros, F. Sáez, M. J. Negro, and P. Manzanares, "Optimizing Liquid Hot Water pretreatment conditions to enhance sugar recovery from wheat straw for fuel-ethanol production," Fuel, vol. 87, no. 1718, pp. 3640-3647, 2008.

[11] C. Cristóbal, R. Inmaculada, O. Jose, S. Felicia, and C. Eulogio, "Liquid hot water pretreatment of olive tree pruning residues," Applied Biochemistry and Biotechnology, vol. 137-140, no. 112, pp. 379-394, 2007.

[12] C. Wan and Y. Li, "Effect of hot water extraction and liquid hot water pretreatment on the fungal degradation of biomass feedstocks," Bioresource Technology, vol. 102, no. 20, pp. 9788 9793, 2011.

[13] H. K. Sreenath, R. G. Koegel, A. B. Moldes, T. W. Jeffries, and R. J. Straub, "Enzymic saccharification of alfalfa fibre after liquid hot water pretreatment," Process Biochemistry, vol. 35, no. 1-2, pp. 33-41, 1999.

[14] G. Peter Van Walsum, M. Garcia-Gil, S. F. Chen, and K. Chambliss, "Effect of dissolved carbon dioxide on accumulation of organic acids in liquid hot water pretreated biomass hydrolyzates," Applied Biochemistry and Biotechnology, vol. 137-140, no. 1-2, pp. 301-311, 2007.

[15] J. A. Pérez, A. González, J. M. Oliva, I. Ballesteros, and P. Manzanares, "Effect of process variables on liquid hot water pretreatment of wheat straw for bioconversion to fuelethanol in a batch reactor," Journal of Chemical Technology and Biotechnology, vol. 82, no. 10, pp. 929-938, 2007.

[16] T. Ingram, T. Rogalinski, V. Bockemühl, G. Antranikian, and G. Brunner, "Semi-continuous liquid hot water pretreatment of rye straw," The Journal of Supercritical Fluids, vol. 48, no. 3, pp. 238-246, 2009.

[17] B. Adney and J. Baker, Measurement of Cellulase Activities. LAP-006 NREL Analytical Procedure, National Renewable Energy Laboratory, Golden, Colo, USA, 1996.

[18] T. K. Hayward, N. S. Combs, S. L. Schmidt, and G. P. Philippidis, SSF Experimental Protocols: Lignocellulosic Biomass Hydrolysis and Fermentation, National Renewable Energy Laboratory, Golden, Colo, USA, 1995.

[19] A. Sluiter, B. Hames, R. Ruiz et al., Determination of Structural Carbohydrates and Lignin in BiomassNational Renewable Energy Laboratory, Golden, Colo, USA, 2008.

[20] G. L. Guo, D. C. Hsu, W. H. Chen, W. H. Chen, and W. S. Hwang, "Characterization of enzymatic saccharification for acid-pretreated lignocellulosic materials with different lignin composition," Enzyme and Microbial Technology, vol. 45, no. 2, pp. $80-87,2009$.

[21] H. K. Tae and Y. Y. Lee, "Pretreatment and fractionation of corn stover by ammonia recycle percolation process," Bioresource Technology, vol. 96, no. 18, pp. 2007-2013, 2005.

[22] K. Öhgren, R. Bura, J. Saddler, and G. Zacchi, "Effect of hemicellulose and lignin removal on enzymatic hydrolysis of steam pretreated corn stover," Bioresource Technology, vol. 98, no. 13, pp. 2503-2510, 2007.

[23] L. Liu, J. Sun, M. Li, S. Wang, H. Pei, and J. Zhang, "Enhanced enzymatic hydrolysis and structural features of corn stover by
$\mathrm{FeCl}_{3}$ pretreatment," Bioresource Technology, vol. 100, no. 23, pp. 5853-5858, 2009.

[24] B. S. Donohoe, S. R. Decker, M. P. Tucker, M. E. Himmel, and T. B. Vinzant, "Visualizing lignin coalescence and migration through maize cell walls following thermochemical pretreatment," Biotechnology and Bioengineering, vol. 101, no. 5, pp. 913-925, 2008.

[25] Z. Xiao, X. Zhang, D. J. Gregg, and J. N. Saddler, "Effects of sugar inhibition on cellulases and $\beta$-glucosidase during enzymatic hydrolysis of softwood substrates," Applied Biochemistry and Biotechnology A, vol. 115, no. 1-3, pp. 1115-1126, 2004.

[26] Y. Lu, B. Yang, D. Gregg, J. N. Saddler, and S. D. Mansfield, "Cellulase adsorption and an evaluation of enzyme recycle during hydrolysis of steam-exploded softwood residues," Applied Biochemistry and Biotechnology A, vol. 98-100, pp. 641-654, 2002.

[27] A. Mohagheghi, M. Tucker, K. Grohmann, and C. Wyman, "High solids simultaneous saccharification and fermentation of pretreated wheat straw to ethanol," Applied Biochemistry and Biotechnology, vol. 33, pp. 67-81, 1992. 

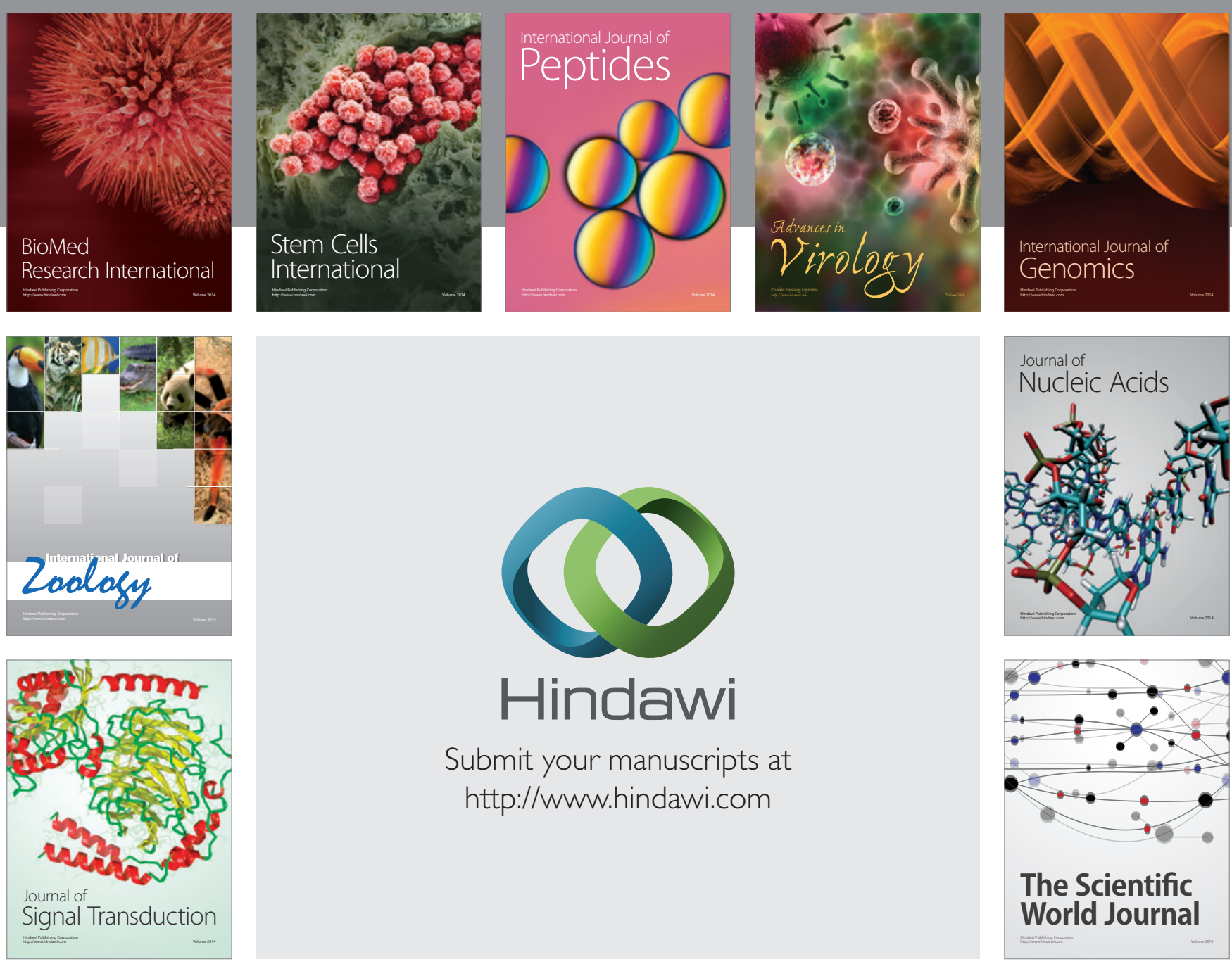

Submit your manuscripts at

http://www.hindawi.com
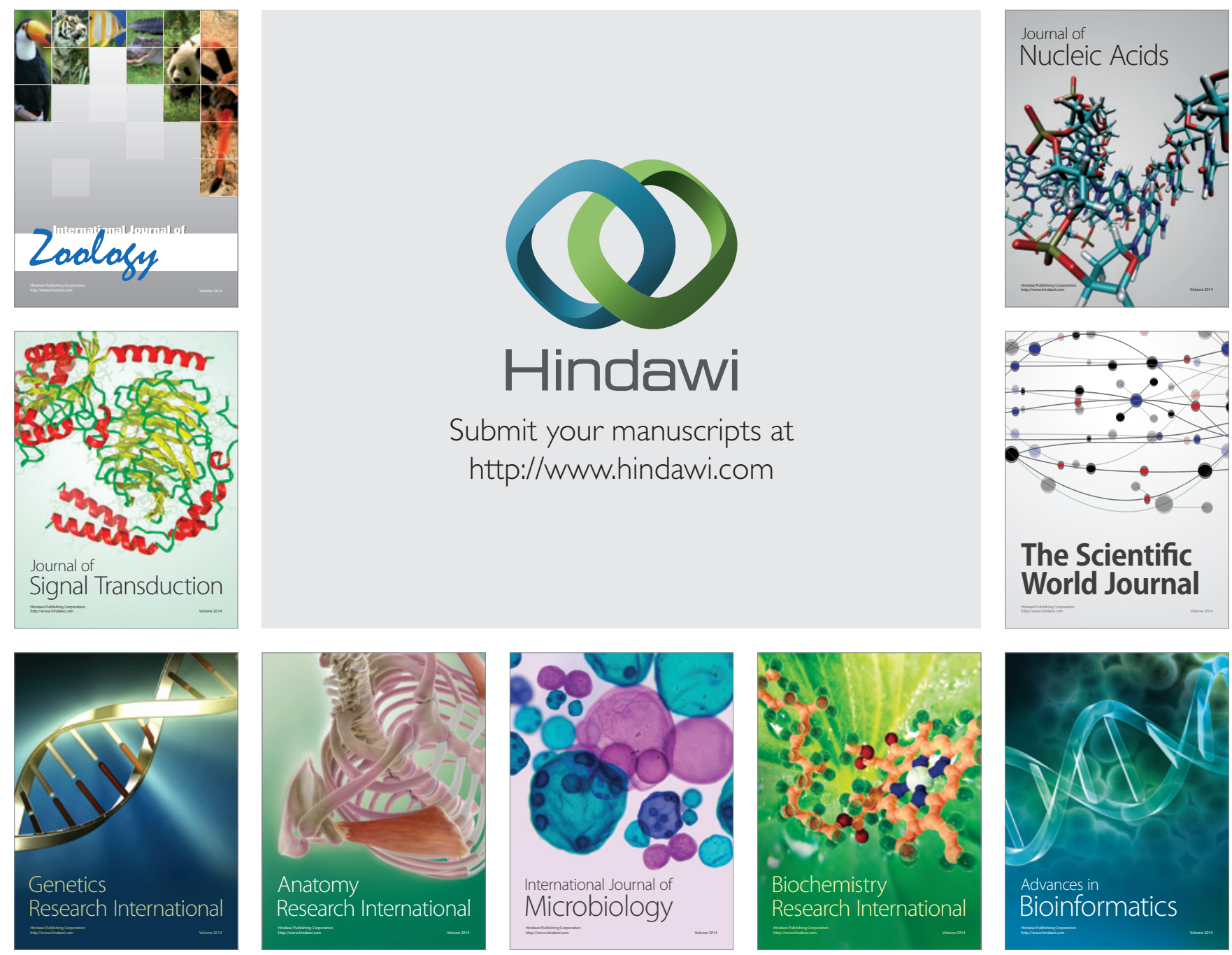

The Scientific World Journal
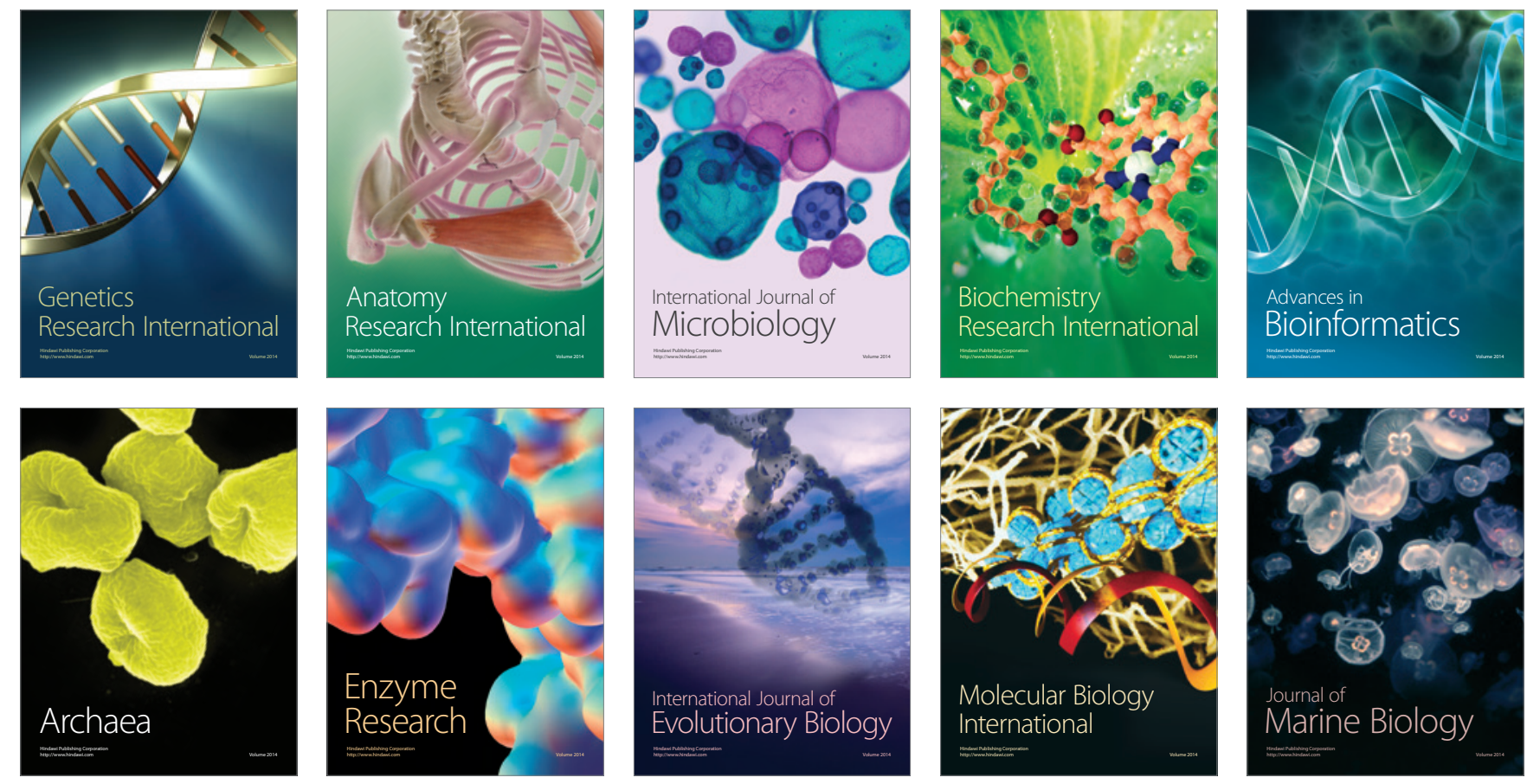